\title{
WATERSHED PRIORITIZATION ACROSS ERBIL PROVINCE FOR SOIL EROSION MANAGEMENT VIA MORPHOMETRIC ANALYSIS
}
K. M. Mohammed ${ }^{1}$
Assist. Lecturer
T. H. Karim ${ }^{1}$
Prof.

${ }^{1}$ Dept. Soil and Water Coll. Agric. Engin. Sci. Salahaddin University-Erbil- Iraq. ABSTRACT

kamyar.mohammed@su.edu.krd

Soil erosion is one of the foremost factors giving rise to watershed deterioration due to improper and unwise utilization of natural resources without proper vision, particularly in developing countries like Iraq. Since it is not possible to implement rehabilitation programs over all areas at a time, prioritization plays a major role in identification of the areas which are in need of immediate actions. Accordingly, the current study was conducted to perform morphometric analysis as the basis for prioritization. To achieve the above objective, 30 watersheds of different scales were delineated within Erbil governorate and standard procedures were followed to carry out morphometric analysis. Prioritization ranks were determined for the study watersheds based on computation of compound factors and on the technique for order preference by similarity to ideal solution (TOPSIS). The results indicated that nearly two approaches offered similar results. The regression analysis indicated that the priority rank from (TOPSIS) can be predicted from the priority rank from compound factor computation with a reasonable accuracy. Based on TOPSIS approach, watersheds: Kawlan-smelan, Nawandee, Warte, Prdi-qasre, Nawprdan, Darbandy-rayat, Dargalla and Mergasor fall within the very high priority class and as a consequence immediate actions should be taken to protect these watersheds. By contrast, the watersheds: Kasnazan, Smaquly, Bestana, Kawanyan, Rulka and Degala 1 are categorized under the low prioritization level. Further improvements in specifying the priority ranks can be expected upon coupling land use/land cover with morphometric analysis.

Keywords: watershed ranking, compound factor, prioritization techniques, watershed attributes

محمد و كريم

1275-1262:51: 2020 - مجلة العلوم الزراعية العراقية

تحديد أولويات احواض الانهر من خلال التحليل المورفوميترى للسيطرة على التعرية المائية ضمن محافظة أربيل

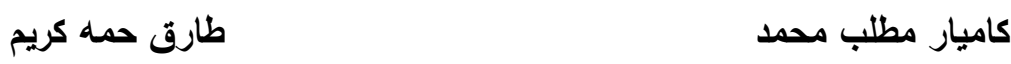

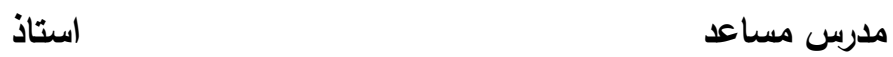

$$
\begin{aligned}
& \text { قسم علوم الترية و المياه- كلية علوم الهندسة الزراعية - جامعة صلاح الدين - اربيل }
\end{aligned}
$$

تعد التعرية المائية أحدى العوامل المؤدية إلى تدهور احواض الاتهر بسبب الاستخدام غير السليم للموارد الطبيعية ودون روئة مناسبة

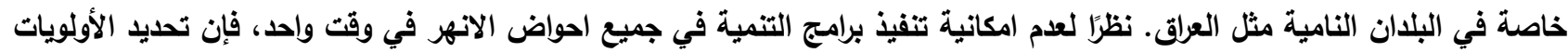

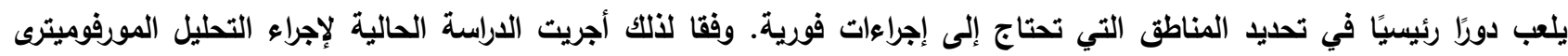

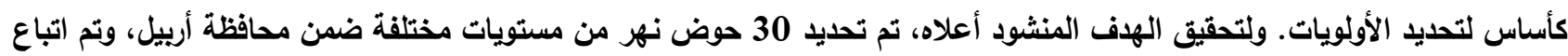

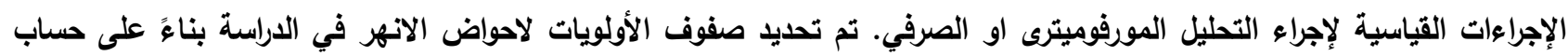

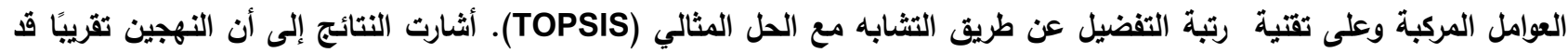

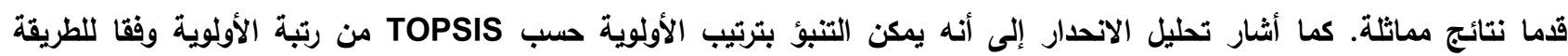

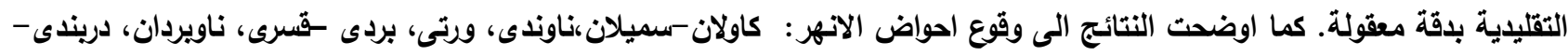

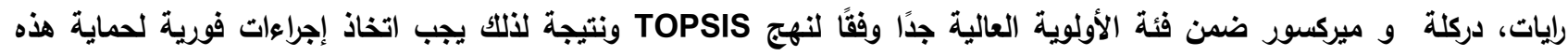
الاحواض الانهر. على النقيض من ذلك، تم تصنيف احواض الانهر: كسنزان، سماقولى، بيستانة، كاوانيان، رولكة و ديكلة 1 تحت مستوى

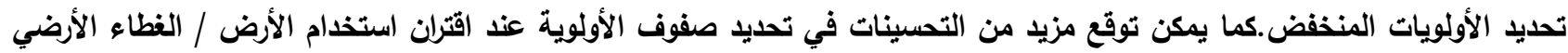
بالتحليل المورفوميتري. كلمات مفتاحية: ترتب احواض الانهر، العامل المركب، طرق تحديد الأولويات، خصائص احواض الانهر . 


\section{INTRODUCTION}

Soil erosion is one of the foremost factors giving rise to land degradation (43). The notion of land degradation originates from soil degradation, as a synonym for land degradation (17). It can be defined as deterioration of land quality and productivity in a given area of interest (15). It causes soil resources exploitation; lowers land productivity and changes the composition of vegetation's (43). Furthermore, Vittala et al. (39) reported that watershed deterioration is a common phenomenon worldwide due to improper and unwise utilization of natural resources without proper vision, particularly in developing countries. This problem is a subject of urgency and should be given higher priority on the environmental agenda (1). Accelerated erosion in watersheds can be minimized through identification and prioritizations of sensitive regions to soil erosion (5). In some studies by Baumgardner (4) the characteristics of basin morphometry have been used for predicting flood peak, assessing sediment yield and erosion rates. By morphometry is meant, measurement and mathematical analysis of earth surface configuration, shape and landforms dimensions (8). Tavassol and GS (37) reported that the assessment of basin hydrologic characteristics is a mandate basin management schemes. It includes basin size, shape, slope, drainage density besides length and size of the existing streams. As linear and shape parameters of watershed morphometric characteristics have direct and indirect relationship with soil erodibility, they can be used as basis for prioritization (14). This implies that the quantitative analysis of drainage basins can be considered as a basic technique for watershed prioritization (12). Watershed prioritization is a technique of ranking subwatersheds based on degree of denudation caused by accelerated erosion and criticality state of the drainage basins (24). Sujatha et al. (34) reported that geomorphometric analysis has wide applications and can be considered as an indirect assessment tool for estimating soil erosion, land slide susceptibility besides groundwater and topography analyses. Puno and Puno (26) stated that the criteria for ranking do not include only geomorphometric factors, but it also encompasses the average soil loss, land use or land cover, and other pertinent factors. Vittala et al. (39) demonstrated that it is not possible to implement rehabilitation programs over all areas at a time. For this reason, prioritization plays a major role in identification of the areas which are in need of immediate actions. It is commendable to mention that the study watersheds are under the threat of degradation due to uncontrolled agricultural activities and most of didn't have the required database for decision making. Under this situation, the morphometric analysis is of enormous usefulness (35), in the prioritization of soil conservation at a watershed level because the agricultural activity plays a major role in socio-economic development Accordingly, the current study was conducted and the main objectives were: to conduct quantitative morphometric analysis as a basic technique for characterizing the existing watersheds within Erbil province and to prioritize these watersheds based on morphometric analysis by computing compound factor and using TOPSIS MCDM approach.

\section{MATERIALS AND METHODS \\ Brief description of the study area}

The study area is located in the realm at the mountainous area of Erbil province, Iraq, which lies within the geographical coordinates of $35^{\circ} 30^{\prime} 00^{\prime \prime}$ to $37^{\circ} 15^{\prime} 00^{\prime \prime}$ north latitudes and from $43^{\circ} 30^{\prime} 00^{\prime \prime}$ to $45^{\circ} 15^{\prime} 00^{\prime \prime}$ East longitudes. The whole study region is covering an area of $47285 \mathrm{~km}^{2}$ and feeding the Greater $\mathrm{Zab}$ and the Lesser Zab are the major upland tributaries of the Tigris River (Figure 1). Several basins at the lower part of the study area fall in the semiarid class $(0.2<\mathrm{AI}<0.5)$, while the remaining basins fall in the dry subhumid class $(0.5<\mathrm{AI}<0.65)$ according to the aridity index (AI) proposed by (38). Furthermore, based on the annual and monthly averages of temperature and precipitation for the study area, with no exception, the study basins fall in $\mathrm{C}_{\mathrm{sa}}$ climatic class according to the scheme proposed by Koppen. The study region is characterized by having a broad range of annual precipitation from about $400 \mathrm{~mm}$ at its lower part to more than $1000 \mathrm{~mm}$ at the 
borders. The rainfall has a unimodal the months of December to March. distribution and there is water surplus during

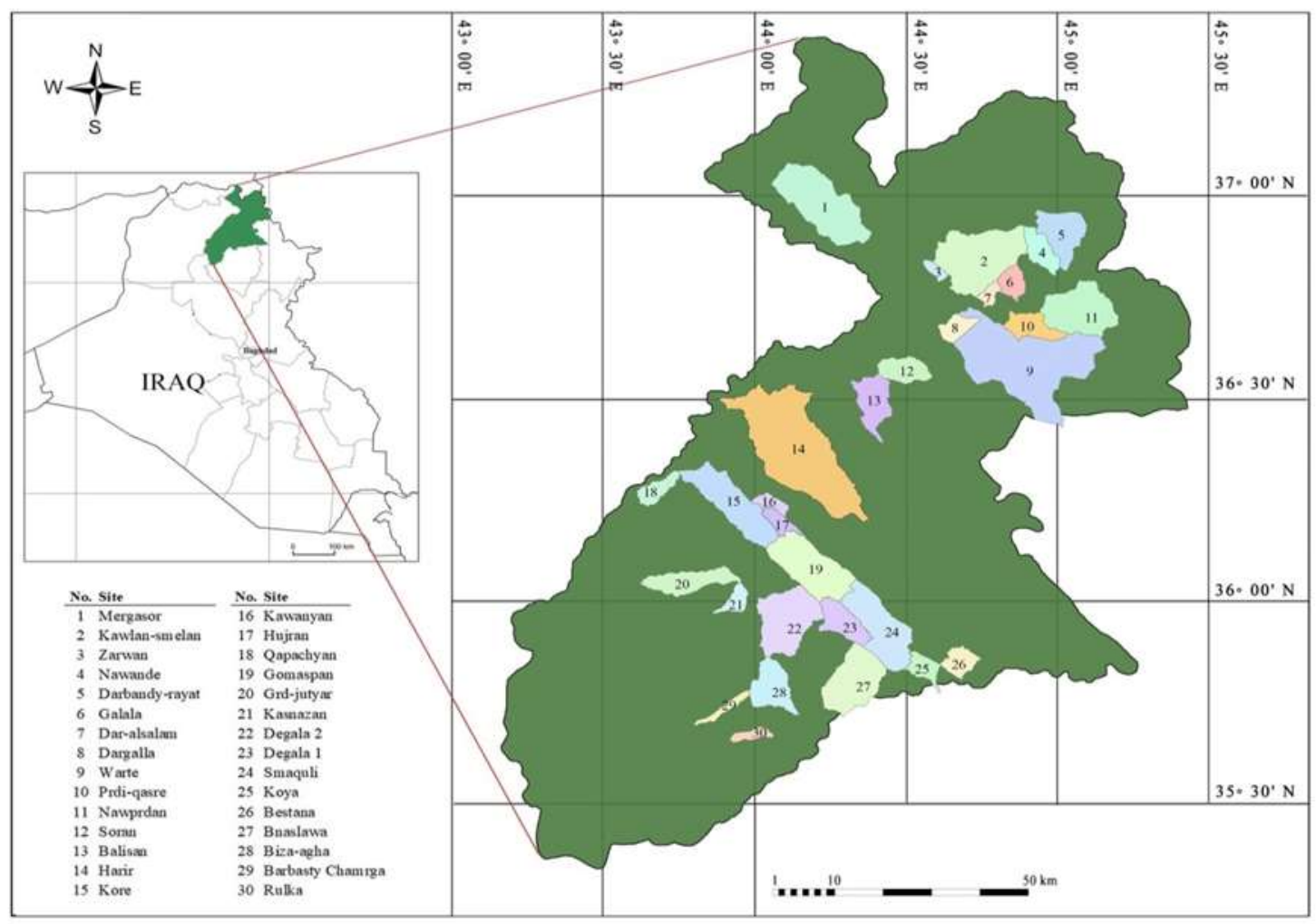

Figure1. Location map showing the delineated watersheds under study

Most of the study area, particularly its middle and upper parts can be generally described as rough broken and stony lands. These soils are either truncated or completely removed so that the diagnostic horizons of all orders other than Entisols are absent in most cases. The existing soils are variables due to variation in exposure, runoff, relief, parent materials, soil depth and maturity (6). The most common great groups on the sloppy lands are Rendolls and Xerorthents. On the other hand, Calcixerolls and Chromoxererts are the most abundant great groups over the plains intermountain valley. Considerable area were occupied by forest lands in the past, but at the present, the forest density ranges from treeless lands near the urban areas to very dense forestlands at remote places. The dominant forest tree species is oak trees. The majority of the agricultural lands are rain fed, wheat, barley, lentil, chick pea and faba bean are the principal winter crops.

Measurement of morphometric parameters This approach required a digital elevation model as a base input for specifying topographic and other features in the study area (42). The DEM of district was downloaded from http://earthexplorer usgs.gov/ after registering and logging in. The study area was partitioned into 30 main catchment delineations and each of these catchments was further divided into a group of subcatchments depending on the nature of each main catchments using ArcMap v. 10.Furthermore, the same software was employed for deriving basic parameters to illustrate the morphometric characteristics of the 30 watersheds. The parameters encompassed area, perimeter, basin length, total length of stream segments and slope. These databases were used for characterizing the basins in term of morphometric parameters, which fell in three categories, namely, linear, areal and relief. The different morphometric parameters were determined using standard methodologies $(11,16,22,30$ and 34). The procedure followed by Strahler (33) was followed to determine the stream orders of the study basin.

\section{Prioritization procedure}

1. Five linear, four shapes and three relief features parameters were regarded as erosion risk parameters and considered in the prioritization of the study watershedsTable1. 
Table 1. The decision matrix used for ranking the existing watersheds in the study area

\begin{tabular}{|c|c|c|c|c|c|c|c|c|c|c|c|c|c|}
\hline 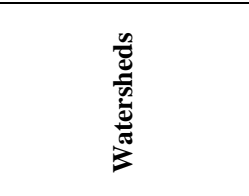 & 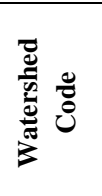 & 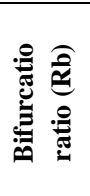 & 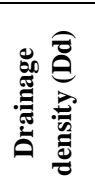 & 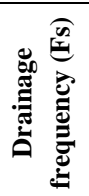 & 莺 & 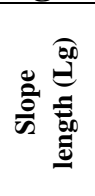 & 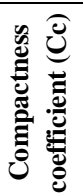 & 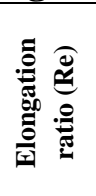 & 国 & 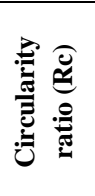 & 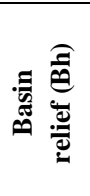 & 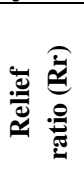 & 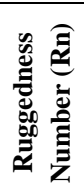 \\
\hline Balisan & WS 1 & 4.094 & 1.476 & 1.374 & 1.546 & 0.368 & 1.562 & 0.851 & 0.569 & 0.416 & 1289 & 0.122 & 1.903 \\
\hline Barbasty Chamrga & WS 2 & 3.500 & 1.876 & 1.010 & 0.356 & 0.274 & 2.222 & 0.371 & 0.108 & 0.206 & 391 & 0.036 & 0.734 \\
\hline Bestana & WS 3 & 3.574 & 1.578 & 1.619 & 1.453 & 0.329 & 1.337 & 0.932 & 0.682 & 0.568 & 500 & 0.074 & 0.789 \\
\hline Biza-agah & WS 4 & 4.391 & 1.248 & 1.429 & 1.158 & 0.371 & 2.316 & 0.795 & 0.497 & 0.189 & 420 & 0.036 & 0.524 \\
\hline Bnaslawa & WS 5 & 8.545 & 1.578 & 1.332 & 1.408 & $\mathbf{0 . 3 3 7}$ & 1.756 & 0.668 & 0.350 & 0.329 & 540 & 0.042 & 0.852 \\
\hline Darbandy-rayat & WS 6 & 3.113 & 1.322 & 1.373 & 1.849 & 0.405 & 1.369 & 0.783 & 0.482 & 0.542 & 2386 & 0.194 & 3.154 \\
\hline Dargalla & WS 7 & 3.278 & 1.307 & 1.588 & 1.266 & 0.412 & 1.309 & 0.706 & 0.392 & 0.592 & 1861 & 0.226 & 2.432 \\
\hline Dar-alsalam & WS 8 & 3.500 & 1.319 & 1.315 & 0.663 & 0.399 & 1.430 & 0.648 & 0.330 & 0.496 & 1407 & 0.225 & 1.856 \\
\hline Degala 1 & WS 9 & 4.311 & 1.252 & 1.443 & 1.951 & 0.363 & 1.342 & 1.196 & 1.124 & 0.563 & 639 & 0.084 & 0.800 \\
\hline Degala 2 & WS 10 & 5.315 & 2.006 & 1.543 & 2.648 & 0.360 & 1.330 & 0.914 & 0.656 & 0.574 & 764 & 0.055 & 1.533 \\
\hline Galala & WS 11 & 3.367 & 1.160 & 1.598 & 1.364 & $\mathbf{0 . 3 3 7}$ & 1.230 & 0.781 & 0.479 & 0.670 & 1809 & 0.239 & 2.098 \\
\hline Gomaspan & WS 12 & 2.365 & 1.490 & 1.656 & 2.804 & 0.352 & 1.372 & 1.325 & 1.380 & 0.539 & 1156 & 0.119 & 1.722 \\
\hline Grd-jutyar & WS 13 & 4.045 & 2.311 & 1.176 & 1.080 & 0.294 & 1.804 & 0.610 & 0.293 & 0.312 & 672 & 0.049 & 1.553 \\
\hline Harir & WS 14 & 4.486 & 1.624 & 1.487 & 3.642 & 0.382 & 1.666 & 0.830 & 0.541 & 0.366 & 1453 & 0.057 & 2.360 \\
\hline Hujran & WS 15 & 5.000 & 1.375 & 0.923 & 0.649 & 0.364 & 1.543 & 0.767 & 0.462 & 0.426 & 1108 & 0.166 & 1.524 \\
\hline Kasnazan & WS 16 & 2.833 & 1.436 & 1.371 & 0.857 & 0.334 & 1.467 & 0.728 & 0.417 & 0.471 & 429 & 0.061 & 0.616 \\
\hline Kawanyan & WS 17 & 4.400 & 1.333 & 1.606 & 0.921 & 0.334 & 1.485 & 1.211 & 1.152 & 0.460 & 570 & 0.155 & 0.760 \\
\hline Kawlan-smelan & WS 18 & 3.920 & 1.289 & 1.416 & 2.980 & 0.378 & 1.336 & 0.949 & 0.708 & 0.568 & 4647 & 0.298 & 5.990 \\
\hline Kore & WS 19 & 5.390 & 1.456 & 1.502 & 2.214 & 0.359 & 1.670 & 0.586 & 0.269 & 0.364 & 934 & 0.043 & 1.368 \\
\hline Koya & WS 20 & 3.078 & 1.545 & 1.595 & 0.985 & 0.305 & 1.610 & 0.578 & 0.262 & 0.391 & 717 & 0.071 & 1.108 \\
\hline Mergasor & WS 21 & 6.096 & 1.524 & 1.481 & 3.141 & 0.380 & 1.350 & 0.673 & 0.356 & 0.557 & 1476 & 0.067 & 2.249 \\
\hline Nawandee & WS 22 & 3.778 & 1.776 & 2.219 & 1.645 & 0.377 & 1.608 & 0.541 & 0.230 & 0.393 & 2427 & 0.217 & 3.201 \\
\hline Nawprdan & WS 23 & 3.426 & 1.434 & 1.520 & 2.798 & 0.393 & 1.268 & 0.811 & 0.517 & 0.631 & 2513 & 0.165 & 3.604 \\
\hline Prdi-qasre & WS 24 & 3.894 & 1.330 & 1.797 & 1.661 & 0.355 & 1.522 & 0.868 & 0.592 & 0.438 & 2548 & 0.296 & 3.389 \\
\hline Qapachyan & WS 25 & 3.583 & 1.435 & 1.731 & 1.346 & 0.303 & 1.508 & 0.594 & 0.277 & 0.446 & 319 & 0.032 & 0.458 \\
\hline Rulka & WS 26 & 3.833 & 0.763 & 0.665 & 0.649 & 0.339 & 1.178 & 0.848 & 0.566 & 0.732 & 333 & 0.048 & 0.254 \\
\hline Smaquly & WS 27 & 3.974 & 1.554 & 1.547 & 2.466 & 0.323 & 1.550 & 1.088 & 0.929 & 0.423 & 756 & 0.065 & 1.175 \\
\hline Soran & WS 28 & 6.500 & 1.426 & 1.312 & 1.405 & 0.355 & 1.302 & 0.745 & 0.436 & 0.599 & 274 & 0.032 & 0.390 \\
\hline Warte & WS 29 & 3.444 & 1.226 & 1.490 & 3.388 & 0.437 & 1.745 & 0.688 & 0.372 & $\mathbf{0 . 3 3 3}$ & 2854 & 0.095 & 3.499 \\
\hline Zarwan & WS 30 & 3.625 & 1.080 & 1.696 & 0.874 & 0.349 & 1.297 & 0.434 & 0.148 & 0.603 & 1133 & 0.134 & 1.224 \\
\hline $\begin{array}{l}\text { 2. The highe } \\
\text { a direct rela }\end{array}$ & lue & eac & ra & $r$ & & & & $\bar{X}$ & & & & & \\
\hline
\end{tabular}

relationship with erodibility was rated as rank one.

3. The compound value was calculated for each watershed after adding the corresponding ranks of all the morphometric parameters that were considered for prioritization and the results were divided by number of the parameters.

4. The watershed with the lowest compound factor was assigned the highest priority.

5. The TOPSIS model was also implemented for classifying the watersheds into priority classes according to the procedure described by (23). The details of the procedure are as follows:

The normalized decision matrix, $\mathrm{R}$, was computed from the decision matrix $\mathrm{X}_{\mathrm{ij}}$ by using the following relationship:
To obtain the weighted normalized matrix $\mathrm{V}$, each column of matrix $\mathrm{R}$ was multiplied by the corresponding weight $\left(\mathrm{W}_{\mathrm{j}}\right)$ :

$\mathrm{V}_{\mathrm{ij}}=\mathrm{R}_{\mathrm{ij}} \mathrm{W}_{\mathrm{j}}$

Upon attaining the positive ideal and negative ideal solutions from weighted normalized matrix, the separation measures from the positive ideal $\left(\mathrm{S}_{\mathrm{i}}^{+}\right)$and the negative ideal $\left(\mathrm{S}_{\mathrm{i}}^{-}\right)$ solutions were calculated for all the watersheds according to:

$\mathbf{S}_{\mathbf{i}}{ }^{+}=\sqrt{\sum_{\mathbf{j}=\mathbf{1}}^{\mathbf{n}}\left(\mathbf{V}_{\mathbf{i j}}-\mathbf{V}_{\mathbf{j}}{ }^{+}\right)^{\mathbf{2}}}$

$S_{i}{ }^{-}=\sqrt{\sum_{j=1}^{n}\left(V_{i j}-V_{j}{ }^{-}\right)^{2}}$ 
Thereafter, the following formula was applied to determine the relative closeness to the ideal solution.

$$
\mathbf{C}_{\mathbf{i}}^{+}=\frac{\mathbf{S}_{\mathbf{i}}^{-}}{\mathbf{S}_{\mathbf{i}}^{+}+\mathbf{S}_{\mathbf{i}}^{-}}
$$

\section{RESULTS AND DISCUSSION}

\section{General aspects about the delineated watersheds}

As a whole the study watersheds having $4^{\text {th }}$ order streams covering areas varying from as low as 1061.2 ha to as high as 34901.9 ha. Based on the classification scheme reported by Suresh (36), $70 \%$ of them fall in the Milliwatershed class (1000 - 10000 ha). Based on the classification scheme proposed by Walsh and Lawler (40), most of the stations at the lower part of the study area like Ankawa, Qushtapa and Khabat showed markedly seasonal with a long drier season ( $\mathrm{SI}=0.80$ - 0.99). By contrast, the stations within the mountainous area showed rather seasonal (SI= $0.40-0.59)$ to seasonal $(\mathrm{SI}=0.6$ - 0.79) rainfall distribution. The majority of the watersheds are $4^{\text {th }}$ order basins with dendritic drainage pattern, signifying moderate contribution of runoff and sediments into the existing channels. The prioritization was based on morphometric analysis. The watershed attributes encompasses some selected linear, areal and relief features parameters. The obtained data were cross tabulated in (Table 1).

\section{Linear aspects}

The drainage density varies from as low as 0.763 for WS26 to as high as 2.311 for WS13 (Table 1). It can also be observed that the majority of watersheds (more than 93\%) have drainage density of less than $2 \mathrm{~km}^{-1}$. Except for watershed WS10 and WS13, all the study watersheds fell in the low class $\left(0-2 \mathrm{~km}^{-1}\right)$. Relatively low relief, dense vegetation cover and permeable subsoil are responsible for low drainage density (41). The drainage density values presented in Table 1 suggest that the watersheds are underlain by permeable materials and characterized by having dense vegetation and relatively low relief. Furthermore, they have relatively slow hydrologic response to rainfall events. Srivastave et al., (32) reported that a basin with a low drainage density has a slow hydrologic response.It is obvious from Table 1 that the bifurcation ratio ranges from a minimum of 2.365 for WS12 to a maximum of 8.545 for WS5 and the remaining watersheds fell between these two extremes. The results also indicated that the majority of bifurcation ratio fell in the range of 3-4.5 with average values of 4.16 . These moderate values indicated moderate overland flow and moderate recharge for the study watersheds. Nag (22) reported that low value for the bifurcation ratio reflects partially disturbed without any distortion in drainage pattern. On the other hand, high bifurcation is an indicative of remarkable distortion by geological structure. It is also obvious from Table 1 that the drainage frequency varies from as low as 0.665 in WS26 to as high as 2.219 for WS22. Close examination of Table 1 discloses that with one exception, all the watersheds fell in poor class $\left(\mathrm{Fs}<2.0 \mathrm{~km}^{-2}\right.$ ) based on the scheme shown by (19). This parameter is basin lithology dependents and is an indication of the basin drainage network texture (31). The low drainage frequency for the study watersheds indicates that the watersheds are bearing low relief and having conducting subsurface materials (28). It is also evident from Table 1 that the texture ratio ranges from as low as 0.356 for WS2 to as high as 3.642 for WS14 and the rest of the watersheds fell between these two extremes. This implies that the value of this parameter is below 4. Such values are indications of the fact that the watersheds are of moderate runoff (12). The semiarid climate along with nonintensive vegetative cover may be responsible for the coarse texture of the study watersheds.

\section{Areal aspects}

The results of Table 1 also show that the circularity ratio values (Rc) vary from a minimum of 0.189 for WS4 to a maximum of 0.732 for WS26.This implies that there is a wide variation in watershed shape across the study area. No Rc value falls above 0.75 evidencing that no watershed has a circular or close to a circular shape. More than $66 \%$ of the Rc values are in the range of $0.40-0.70$. This implies that the shape of the majority of the watersheds is intermediate between elongated and circular shape. According to Miller (2), most of the watersheds are characterized by 
having permeable and homogeneous geologic materials. $=====$ Furthermore, the intermediate shape for most of the watersheds is an indication that most of the watersheds are at medium stage of topographical maturity (18). Regarding the influence of shape on hydrologic response, there are conflicting reports. For instance, it was reported that a circular shaped basin takes long time to reach excess water to the basin outlet (31). This statement was supported by Arabameri et al. (3) who demonstrated that lower values of shape parameters indicating higher susceptibility to erosion. By contrast, many researchers, for instance, Farhan and Anaba (12) have shown that a circular basin is more efficient in runoff inducement than an elongated one. Similarly, Singh and Singh (30) reported that a circular basin is more efficient in the discharge of runoff than an elongated watershed. The results presented in Table 1 also reveal that the values of the elongation ratio are characterized by a wide variation, falling in between 0.371 for WS2 to 1.325 for WS12. About $67 \%$ of the presented values fell in between 0.6 and 1.0. This finding is in concordant with Schumm (3) findings, who reported that the values of elongation ratio generally vary between 0.6 and 1.0 over a wide range of geological and climatic environments. Close inspection of the results also revealed that the majority of the study watersheds $(60 \%)$ fall in less elongated $(0.7-$ $0.8)$, elongated (0.5-0.7) and more elongated $(\operatorname{Re}<0.5)$ and the rest of the watersheds falls in the oval and circular categories ( $\operatorname{Re}>0.8)$. Watershed with Re values in the range of 0.6 0.8 are representing watersheds with high rugged relief and steep slopes (13). As mentioned earlier, conflicting results are found in literature about the effect of the shape parameters about the hydrologic response of the watershed. However, Da Cunha and Bacani (9) reported that a more elongated shape facilitates the runoff of water, which has a higher tendency to support erosion process. Similarly, Said et al. (29) revealed that the lower the value of the basin shape, the more will be the erodibility. Based on the obtained values of $\mathrm{Re}$, it can be inferred that the obtained values are usually associated with high relief. It is worthy to mention that the analysis of form factor leads to similar conclusions. For instance, the present values of form factor are concomitant with those of elongation ratio. This implies the higher the elongation ratio the higher will be the form factor and vice versa. The Pearson's correlation coefficient is more than 0.98 . On the contrary, it was observed that the compactness coefficient (Cc) was negatively correlated with the elongation ratio. However the majority of the $\mathrm{C}_{\mathrm{c}}$ values are in the range of $1.0-2.0$. The compactness coefficient close to 1 is for circular shaped basins, while the high values of this parameter indicate high degree of zigzagging and low flood (10). The length of overland flow is quietly synonymous with the length of sheet flow and approximately equals half the reciprocal of the drainage density (7). It can also be noticed from Table 1 that the slope length varies from as low as $0.274 \mathrm{~km}$ for WS2 to as high as $0.437 \mathrm{~km}$ for WS29. Additionally it can be observed that most of the study watersheds have slope lengths exceeding $0.30 \mathrm{~km}$. A high value of slope length means gentle slopes and long flow paths more infiltration, and reduced runoff (27). Previous research revealed that the shorter the slope length, the faster will be the surface runoff from the streams.

\section{Relief aspects}

The relief aspects of the water under study encompass basin relief; relief ratio and ruggedness value (Table 1). The presented data in Table 1 discloses that with the one exception all the watersheds have basin relief of more than $300 \mathrm{~m}(0.3 \mathrm{~km})$. This implies that judging from the basin relief the study area is characterized by having high relief $(\mathrm{Bh}>0.30$ m) (42). On the other hand, more than $56 \%$ of the watersheds fall in the weak relief ratio class $(\mathrm{Rr}<0.1)(29)$. The higher values of relief ratio reflects steeper slope and high relief and vice versa. Meshram and Sharma (20) reported that low values of $\mathrm{Rr}$ suggest lesser soil erodibility mainly due to resistant basement rocks and low degree of slope. The results depicted in Table 1 also indicated that the ruggedness values of the study watershed are less than $8 \%$. According to this parameter, all the watersheds fall in the low class (10). Furthermore, the low values of this parameter 
suggest that these watersheds are resistant to erosional process (27).

\section{Watershed prioritization}

Prioritization based on computation of compound factor

This study emphasizes on the prioritization of the study watersheds based on morphometric analysis of the watersheds that has been carried out using mathematical equations. Out of a huge number of watershed attributes, 12 parameters were selected as criteria for prioritization. The criteria are related to linear, shape and relief morphometric attributes. The linear attributes encompassed bifurcation ratio $(\mathrm{Rb})$, drainage density (Dd), drainage frequency $(\mathrm{Fs})$, texture ratio $(\mathrm{Tr})$ and slope length or length of overland flow (Lg). The shape factor included each of elongation ratio $(\mathrm{Re})$, form factor $\left(\mathrm{R}_{\mathrm{f}}\right)$ and circularity ratio $\left(\mathrm{R}_{\mathrm{c}}\right)$. On the other hand the relief feature covered each of basin relief $(\mathrm{Bh})$, relief ratio $(\mathrm{Rn})$ and ruggedness number (Rn) (Table 1). As each of the linear and relief feature parameters has a direct relationship with erodibility, the highest value of each parameter was rated as rank 1 and the second highest value as rank 2 and so forth. On the contrary, it was observed that each of the shape parameters has an inverse relationship with soil erodibility (25). Therefore, the lowest value of each of the shape parameters was rated as rank 1 and the second lowest value was rated as rank 2 and so forth (Table 2). The compound factor $\left(C_{f}\right)$ for each watershed was calculated by summing up the ranks of the abovementioned parameters and dividing the result by (12). Thereafter, the lowest compound factor was rated as rank 1 and the lowest one was rated as rank 30 . Finally, priority group was given to each watershed based on the value of its compound factor (Table 2). It appears from the data presented in Table 2 that the watersheds like WS18, WS22, WS29, WS24, WS23, WS6, WS7 and WS21 fell in the very high priority class. By contrast, the watersheds: WS16, WS27; WS3, WS17, WS26 and WS9 fell in the low priority class.

\section{Prioritization based of TOPSIS}

The same parameters utilized for prioritization according to the compound factor approach, were employed to determine the order of preference according to technique for Order of Preference by Similarity to Ideal Solution (TOPSIS). As mentioned earlier, they are comprised of 5 linear parameters $\left(\mathrm{Rb}, \mathrm{D}_{\mathrm{d}}, \mathrm{F}_{\mathrm{s}}\right.$, $\operatorname{Tr}$ and $\left.\mathrm{L}_{\mathrm{g}}\right) ; 4$ areal or shape parameters $\left(\mathrm{R}_{\mathrm{e}}, \mathrm{F}_{\mathrm{f}}\right.$, $\mathrm{C}_{\mathrm{c}}$ and $\left.\mathrm{R}_{\mathrm{c}}\right)$ and 3 relief features $\left(\mathrm{B}_{\mathrm{h}}, \mathrm{R}_{\mathrm{r}}\right.$ and $\left.\mathrm{R}_{\mathrm{n}}\right)$ (Table 1). The normalized decision matrix, $R$, was computed from the decision matrix $\mathrm{X}$ by using the Eq. [1] (Table 3). To obtain the weighted normalized matrix $\mathrm{V}$, each column of matrix $\mathrm{R}$ was multiplied by the corresponding weight (Table 4). As a first approximation, an equal weight of 0.083 was given to each criterion instead of determining the relative weights by following the Saaty's Analytical Hierarchy Process (AHP). 
Table 2. Prioritized ranks assigned to the erosion risk parameters of the study watersheds

\begin{tabular}{|c|c|c|c|c|c|c|c|c|c|c|c|c|c|c|}
\hline 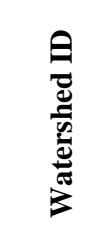 & 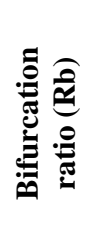 & 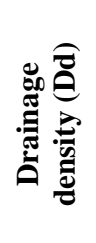 & 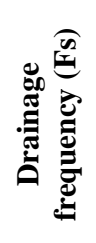 & 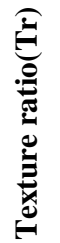 & 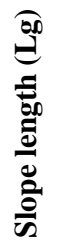 & 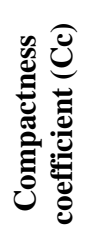 & 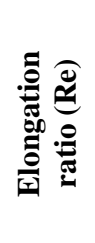 & 兽 & 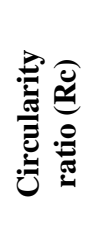 & 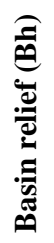 & 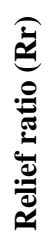 & 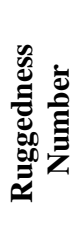 & 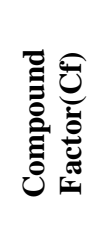 & 节 \\
\hline WS 1 & 11 & 12 & 21 & 14 & 11 & 21 & 22 & 22 & 10 & 12 & 12 & 11 & 14.917 & 14 \\
\hline WS 2 & 21 & 3 & 28 & 30 & 30 & 29 & 1 & 1 & 2 & 27 & 28 & 25 & 18.750 & 25 \\
\hline WS 3 & 20 & 6 & 6 & 15 & 25 & 9 & 25 & 25 & 22 & 24 & 16 & 23 & 18.000 & 23 \\
\hline WS 4 & 9 & 26 & 19 & 21 & 10 & 30 & 18 & 18 & 1 & 26 & 27 & 27 & 19.333 & 28 \\
\hline WS 5 & 1 & 7 & 24 & 16 & 21 & 27 & 9 & 9 & 4 & 23 & 26 & 21 & 15.667 & 16 \\
\hline WS 6 & 27 & 21 & 22 & 11 & 3 & 12 & 17 & 17 & 19 & 6 & 7 & 6 & 14.000 & 10 \\
\hline WS 7 & 26 & 23 & 10 & 20 & 2 & 6 & 12 & 12 & 25 & 7 & 4 & 7 & 12.833 & 7 \\
\hline WS 8 & 21 & 22 & 25 & 27 & 4 & 14 & 8 & 8 & 17 & 11 & 5 & 12 & 14.500 & 13 \\
\hline WS 9 & 10 & 25 & 18 & 10 & 13 & 10 & 28 & 28 & 21 & 21 & 15 & 22 & 18.417 & 24 \\
\hline WS 10 & 5 & 2 & 12 & 7 & 14 & 7 & 24 & 24 & 24 & 17 & 22 & 15 & 14.417 & 11 \\
\hline WS 11 & 25 & 28 & 8 & 18 & 21 & 2 & 16 & 16 & 29 & 8 & 3 & 10 & 15.333 & 15 \\
\hline WS 12 & 30 & 11 & 5 & 5 & 18 & 13 & 30 & 30 & 18 & 13 & 13 & 13 & 16.583 & 20 \\
\hline WS 13 & 12 & 1 & 27 & 22 & 29 & 28 & 7 & 7 & 3 & 20 & 23 & 14 & 16.083 & 18 \\
\hline WS 14 & 7 & 5 & 16 & 1 & 6 & 24 & 20 & 20 & 7 & 10 & 21 & 8 & 12.083 & 4 \\
\hline WS 15 & 6 & 18 & 29 & 28 & 12 & 19 & 15 & 15 & 12 & 15 & 8 & 16 & 16.083 & 18 \\
\hline WS 16 & 29 & 14 & 23 & 26 & 23 & 15 & 13 & 13 & 16 & 25 & 20 & 26 & 20.250 & 29 \\
\hline WS 17 & 8 & 19 & 7 & 24 & 23 & 16 & 29 & 29 & 15 & 22 & 10 & 24 & 18.833 & 27 \\
\hline WS 18 & 14 & 24 & 20 & 4 & 8 & 8 & 26 & 26 & 23 & 1 & 1 & 1 & 13.000 & 9 \\
\hline WS 19 & 4 & 13 & 14 & 9 & 15 & 25 & 5 & 5 & 6 & 16 & 25 & 17 & 12.833 & 7 \\
\hline WS 20 & 28 & 9 & 9 & 23 & 27 & 23 & 4 & 4 & 8 & 19 & 17 & 20 & 15.917 & 17 \\
\hline WS 21 & 3 & 10 & 17 & 3 & 7 & 11 & 10 & 10 & 20 & 9 & 18 & 9 & 10.583 & 2 \\
\hline WS 22 & 17 & 4 & 1 & 13 & 9 & 22 & 3 & 3 & 9 & 5 & 6 & 5 & 8.083 & 1 \\
\hline WS 23 & 24 & 16 & 13 & 6 & 5 & 3 & 19 & 19 & 28 & 4 & 9 & 2 & 12.333 & 5 \\
\hline WS 24 & 15 & 20 & 2 & 12 & 16 & 18 & 23 & 23 & 13 & 3 & 2 & 4 & 12.583 & 6 \\
\hline WS 25 & 19 & 15 & 3 & 19 & 28 & 17 & 6 & 6 & 14 & 29 & 30 & 28 & 17.833 & 22 \\
\hline WS 26 & 16 & 30 & 30 & 29 & 20 & 1 & 21 & 21 & 30 & 28 & 24 & 30 & 23.333 & 30 \\
\hline WS 27 & 13 & 8 & 11 & 8 & 26 & 20 & 27 & 27 & 11 & 18 & 19 & 19 & 17.250 & 21 \\
\hline WS 28 & 2 & 17 & 26 & 17 & 16 & 5 & 14 & 14 & 26 & 30 & 29 & 29 & 18.750 & 25 \\
\hline WS 29 & 23 & 27 & 15 & 2 & 1 & 26 & 11 & 11 & 5 & 2 & 14 & 3 & 11.667 & 3 \\
\hline WS 30 & 18 & 29 & 4 & 25 & 19 & 4 & 2 & 2 & 27 & 14 & 11 & 18 & 14.417 & 11 \\
\hline
\end{tabular}

Upon attaining the positive ideal and negative ideal solutions from weighted normalized matrix, the separation measures from the ideal $\left(\mathrm{S}_{\mathrm{i}}^{+}\right)$and the negative ideal $\left(\mathrm{S}_{\mathrm{i}}^{-}\right)$solutions were calculated for all the watersheds according to Eqs. [3] and [4]. It is interesting to note that the minimum values of the shape factors are in favour of high erodibility, they were considered as negative criteria and the reverse was true for the linear and relief feature parameters. Thereafter, Eq. [5] was applied to determine the relative closeness to the ideal solution and the results were presented in the $4^{\text {th }}$ column of Table 5. Finally, upon ranking the relative closeness of the watersheds in ascending order, the orders of preference of the watersheds were determined and presented in the last column of Table 5 . 
Table 3. The normalized decision matrix for ranking the existing watersheds in the study area

\begin{tabular}{|c|c|c|c|c|c|c|c|c|c|c|c|c|}
\hline 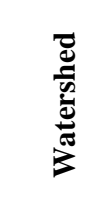 & 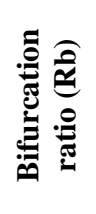 & 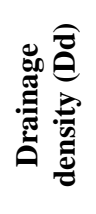 & 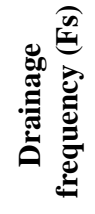 & 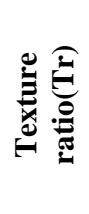 & 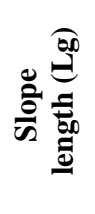 & 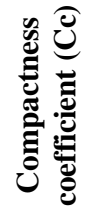 & 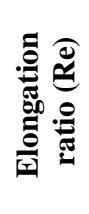 & 国 & 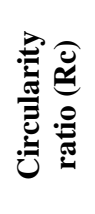 & 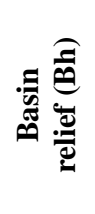 & 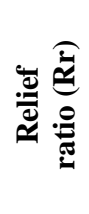 & 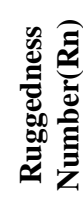 \\
\hline WS 1 & 0.173 & 0.182 & 0.169 & 0.147 & 0.188 & 0.185 & 0.191 & 0.175 & 0.155 & 0.146 & 0.156 & 0.160 \\
\hline WS 2 & 0.148 & 0.232 & 0.124 & 0.034 & 0.140 & 0.264 & 0.083 & $\mathbf{0 . 0 3 3}$ & $\mathbf{0 . 0 7 7}$ & 0.044 & 0.046 & 0.062 \\
\hline WS 3 & 0.151 & 0.195 & 0.199 & 0.138 & 0.168 & 0.159 & 0.209 & 0.209 & 0.211 & 0.057 & 0.096 & 0.066 \\
\hline WS 4 & 0.185 & 0.154 & 0.176 & 0.110 & 0.190 & 0.275 & 0.179 & 0.152 & 0.070 & 0.048 & 0.047 & 0.044 \\
\hline WS 5 & 0.360 & 0.195 & 0.164 & 0.134 & 0.172 & 0.208 & 0.150 & 0.107 & 0.123 & 0.061 & 0.053 & 0.072 \\
\hline WS 6 & 0.131 & 0.163 & 0.169 & 0.176 & 0.207 & 0.162 & 0.176 & 0.148 & 0.202 & 0.271 & 0.250 & 0.266 \\
\hline WS 7 & 0.138 & 0.161 & 0.195 & 0.120 & 0.210 & 0.155 & 0.159 & 0.120 & 0.221 & 0.211 & 0.292 & 0.205 \\
\hline WS 8 & 0.148 & 0.163 & 0.162 & 0.063 & 0.204 & 0.170 & 0.146 & 0.101 & 0.185 & 0.160 & 0.289 & 0.156 \\
\hline WS 9 & 0.182 & 0.155 & 0.177 & 0.185 & 0.185 & 0.159 & 0.269 & 0.345 & 0.210 & 0.072 & 0.109 & 0.067 \\
\hline WS 10 & 0.224 & 0.248 & 0.190 & 0.251 & 0.184 & 0.158 & 0.205 & 0.201 & 0.214 & 0.087 & 0.070 & 0.129 \\
\hline WS 11 & 0.142 & 0.143 & 0.196 & 0.130 & 0.172 & 0.146 & 0.175 & 0.147 & 0.250 & 0.205 & 0.307 & 0.177 \\
\hline WS 12 & 0.100 & 0.184 & 0.203 & 0.266 & 0.180 & 0.163 & 0.298 & 0.423 & 0.201 & 0.131 & 0.153 & 0.145 \\
\hline WS 13 & 0.171 & 0.285 & 0.145 & 0.103 & 0.150 & 0.214 & 0.137 & 0.090 & 0.116 & 0.076 & 0.063 & 0.131 \\
\hline WS 14 & 0.189 & 0.201 & 0.183 & 0.346 & 0.195 & 0.198 & 0.186 & 0.166 & 0.136 & 0.165 & 0.074 & 0.199 \\
\hline WS 15 & 0.211 & 0.170 & 0.113 & 0.062 & 0.186 & 0.183 & 0.172 & 0.142 & 0.159 & 0.126 & 0.214 & 0.128 \\
\hline WS 16 & 0.119 & 0.177 & 0.168 & 0.081 & 0.171 & 0.174 & 0.164 & 0.128 & 0.175 & 0.049 & 0.079 & 0.052 \\
\hline WS 17 & 0.186 & 0.165 & 0.197 & 0.088 & 0.171 & 0.176 & 0.272 & 0.353 & 0.171 & 0.065 & 0.200 & 0.064 \\
\hline WS 18 & 0.165 & 0.159 & 0.174 & 0.283 & 0.193 & 0.159 & 0.213 & 0.217 & 0.212 & 0.527 & 0.383 & 0.504 \\
\hline WS 19 & 0.227 & 0.180 & 0.184 & 0.210 & 0.183 & 0.198 & 0.132 & 0.083 & 0.135 & 0.106 & 0.056 & 0.115 \\
\hline WS 20 & 0.130 & 0.191 & 0.196 & 0.094 & 0.156 & 0.191 & 0.130 & 0.080 & 0.146 & 0.081 & 0.091 & 0.093 \\
\hline WS 21 & 0.257 & 0.188 & 0.182 & 0.298 & 0.194 & 0.160 & 0.151 & 0.109 & 0.207 & 0.167 & 0.086 & 0.189 \\
\hline WS 22 & 0.159 & 0.219 & 0.273 & 0.156 & 0.193 & 0.191 & 0.122 & 0.071 & 0.146 & 0.275 & 0.279 & 0.270 \\
\hline WS 23 & 0.144 & 0.177 & 0.187 & 0.266 & 0.201 & 0.151 & 0.182 & 0.158 & 0.235 & 0.285 & 0.212 & 0.303 \\
\hline WS 24 & 0.164 & 0.164 & 0.221 & 0.158 & 0.181 & 0.181 & 0.195 & 0.182 & 0.163 & 0.289 & 0.381 & 0.285 \\
\hline WS 25 & 0.151 & 0.177 & 0.213 & 0.128 & 0.155 & 0.179 & 0.133 & 0.085 & 0.166 & 0.036 & 0.041 & $\mathbf{0 . 0 3 9}$ \\
\hline WS 26 & 0.162 & 0.094 & 0.082 & 0.062 & 0.173 & 0.140 & 0.191 & 0.173 & 0.272 & 0.038 & 0.062 & 0.021 \\
\hline WS 27 & 0.168 & 0.192 & 0.190 & 0.234 & 0.165 & 0.184 & 0.244 & 0.285 & 0.157 & 0.086 & 0.084 & 0.099 \\
\hline WS 28 & 0.274 & 0.176 & 0.161 & 0.134 & 0.181 & 0.155 & 0.167 & 0.134 & 0.223 & 0.031 & 0.042 & $\mathbf{0 . 0 3 3}$ \\
\hline WS 29 & 0.145 & 0.151 & 0.183 & 0.322 & 0.223 & 0.207 & 0.155 & 0.114 & 0.124 & 0.324 & 0.123 & 0.295 \\
\hline WS 30 & 0.153 & 0.133 & 0.208 & 0.083 & 0.178 & 0.154 & 0.098 & 0.045 & 0.225 & 0.129 & 0.172 & 0.103 \\
\hline
\end{tabular}

Furthermore, the study watersheds are categorized into 4 groups based on the relative closeness to the ideal solution (Table 6). It is evident from the above results (Tables 5 and 6) that watershed: WS18, WS22, WS29, WS24, WS23, WS6, WS7 and WS21 in descending order are very highly vulnerable to soil erosion. Accordingly, these watersheds should be put on to the top agenda to take immediate actions to conserve the natural resources via reducing excess soil and water losses. This will assist addressing the problematic areas to arrive at proper solutions. Soil, agronomic and mechanical measures can be taken to reduce the risk of soil erosion first in the watersheds categorized in very high level of priority level. Examples of mechanical measures are bench terracing, establishment of bunds, percolation tanks contour trenches, recharge shaft, check dams, etc. (7). This ensures the sustainability of agricultural production in the study area. By contrast, the watersheds: WS16, WS27, WS3, WS17, WS26 and WS9 are categorized under the low prioritization level. 
Table 4. The weighted normalized decision matrix for ranking the existing watersheds in the study area

\begin{tabular}{|c|c|c|c|c|c|c|c|c|c|c|c|c|}
\hline$\frac{0}{0}$ & 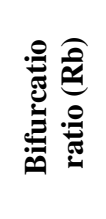 & 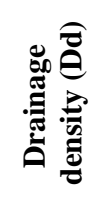 & 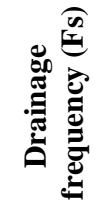 & 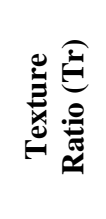 & $\frac{\overparen{\theta 0}}{\stackrel{\Xi}{\Xi}}$ & 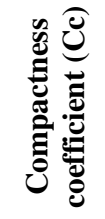 & 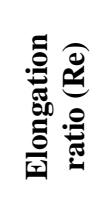 & छ & 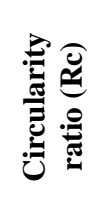 & 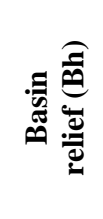 & 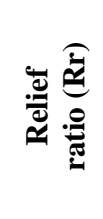 & 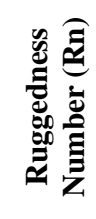 \\
\hline WS 1 & 0.0144 & 0.0152 & 0.0141 & 0.0122 & 0.0157 & 0.0154 & 0.0159 & 0.0145 & 0.0129 & 0.0122 & 0.0130 & 0.0134 \\
\hline WS 2 & 0.0123 & 0.0193 & 0.0103 & 0.0028 & 0.0117 & 0.0220 & 0.0069 & 0.0028 & 0.0064 & $\mathbf{0 . 0 0 3 7}$ & 0.0038 & 0.0051 \\
\hline WS 3 & 0.0126 & 0.0162 & 0.0166 & 0.0115 & 0.0140 & 0.0132 & 0.0174 & 0.0174 & 0.0176 & 0.0047 & 0.0080 & 0.0055 \\
\hline WS 4 & 0.0154 & 0.0129 & 0.0146 & 0.0092 & 0.0158 & 0.0229 & 0.0149 & 0.0127 & 0.0059 & 0.0040 & 0.0039 & 0.0037 \\
\hline WS 5 & 0.0300 & 0.0162 & 0.0136 & 0.0111 & 0.0143 & 0.0174 & 0.0125 & 0.0090 & 0.0102 & 0.0051 & 0.0045 & 0.0060 \\
\hline WS 6 & 0.0109 & 0.0136 & 0.0141 & 0.0146 & 0.0172 & 0.0135 & 0.0147 & 0.0123 & 0.0168 & 0.0226 & 0.0208 & 0.0221 \\
\hline WS 7 & 0.0115 & 0.0135 & 0.0163 & 0.0100 & 0.0175 & 0.0129 & 0.0132 & 0.0100 & 0.0184 & 0.0176 & 0.0243 & 0.0171 \\
\hline WS 8 & 0.0123 & 0.0136 & 0.0135 & 0.0053 & 0.0170 & 0.0141 & 0.0121 & 0.0084 & 0.0154 & 0.0133 & 0.0241 & 0.0130 \\
\hline WS 9 & 0.0152 & 0.0129 & 0.0148 & 0.0154 & 0.0155 & 0.0133 & 0.0224 & 0.0287 & 0.0175 & 0.0060 & 0.0091 & 0.0056 \\
\hline WS 10 & 0.0187 & 0.0207 & 0.0158 & 0.0210 & 0.0153 & 0.0132 & 0.0171 & 0.0168 & 0.0178 & 0.0072 & 0.0059 & 0.0108 \\
\hline WS 11 & 0.0118 & 0.0119 & 0.0164 & 0.0108 & 0.0143 & 0.0122 & 0.0146 & 0.0122 & 0.0208 & 0.0171 & 0.0256 & 0.0147 \\
\hline WS 12 & 0.0083 & 0.0153 & 0.0170 & 0.0222 & 0.0150 & 0.0136 & 0.0248 & $\mathbf{0 . 0 3 5 3}$ & 0.0167 & 0.0109 & 0.0127 & 0.0121 \\
\hline WS 13 & 0.0142 & 0.0238 & 0.0120 & 0.0086 & 0.0125 & 0.0178 & 0.0114 & 0.0075 & 0.0097 & 0.0064 & 0.0052 & 0.0109 \\
\hline WS 14 & 0.0158 & 0.0167 & 0.0152 & 0.0288 & 0.0163 & 0.0165 & 0.0155 & 0.0138 & 0.0113 & $\mathbf{0 . 0 1 3 7}$ & 0.0061 & 0.0166 \\
\hline WS 15 & 0.0176 & 0.0142 & 0.0095 & 0.0051 & 0.0155 & 0.0153 & 0.0143 & 0.0118 & 0.0132 & 0.0105 & 0.0178 & 0.0107 \\
\hline WS 16 & 0.0100 & 0.0148 & 0.0140 & 0.0068 & 0.0142 & 0.0145 & 0.0136 & $\mathbf{0 . 0 1 0 7}$ & 0.0146 & 0.0041 & 0.0066 & 0.0043 \\
\hline WS 17 & 0.0155 & $\mathbf{0 . 0 1 3 7}$ & 0.0164 & 0.0073 & 0.0142 & 0.0147 & 0.0227 & 0.0294 & 0.0143 & 0.0054 & 0.0166 & 0.0053 \\
\hline WS 18 & 0.0138 & 0.0133 & 0.0145 & 0.0236 & 0.0161 & 0.0132 & 0.0178 & 0.0181 & 0.0176 & 0.0439 & 0.0319 & 0.0420 \\
\hline WS 19 & 0.0189 & 0.0150 & 0.0154 & 0.0175 & 0.0153 & 0.0165 & 0.0110 & 0.0069 & 0.0113 & 0.0088 & 0.0046 & 0.0096 \\
\hline WS 20 & 0.0108 & 0.0159 & 0.0163 & 0.0078 & 0.0130 & 0.0159 & 0.0108 & 0.0067 & 0.0121 & 0.0068 & 0.0076 & 0.0078 \\
\hline WS 21 & 0.0214 & 0.0157 & 0.0152 & 0.0249 & 0.0162 & 0.0134 & 0.0126 & 0.0091 & 0.0173 & 0.0140 & 0.0072 & 0.0158 \\
\hline WS 22 & 0.0133 & 0.0183 & 0.0227 & 0.0130 & 0.0161 & 0.0159 & 0.0101 & 0.0059 & 0.0122 & 0.0229 & 0.0233 & 0.0225 \\
\hline WS 23 & 0.0120 & 0.0148 & 0.0156 & 0.0221 & 0.0167 & 0.0125 & 0.0152 & 0.0132 & 0.0196 & 0.0238 & $\mathbf{0 . 0 1 7 7}$ & 0.0253 \\
\hline WS 24 & $\mathbf{0 . 0 1 3 7}$ & 0.0137 & 0.0184 & 0.0131 & 0.0151 & 0.0151 & 0.0163 & 0.0151 & 0.0136 & 0.0241 & 0.0317 & 0.0238 \\
\hline WS 25 & 0.0126 & 0.0148 & 0.0177 & 0.0107 & 0.0129 & 0.0149 & 0.0111 & 0.0071 & 0.0138 & 0.0030 & 0.0034 & 0.0032 \\
\hline WS 26 & 0.0135 & 0.0079 & 0.0068 & 0.0051 & 0.0144 & 0.0116 & 0.0159 & 0.0145 & 0.0227 & 0.0031 & 0.0052 & 0.0018 \\
\hline WS 27 & 0.0140 & 0.0160 & 0.0158 & 0.0195 & 0.0138 & 0.0153 & 0.0204 & 0.0238 & 0.0131 & 0.0071 & 0.0070 & 0.0082 \\
\hline WS 28 & 0.0228 & 0.0147 & 0.0134 & 0.0111 & 0.0151 & 0.0129 & 0.0139 & 0.0112 & 0.0186 & 0.0026 & 0.0035 & 0.0027 \\
\hline WS 29 & 0.0121 & 0.0126 & 0.0153 & 0.0268 & 0.0186 & 0.0173 & 0.0129 & 0.0095 & 0.0103 & 0.0270 & 0.0102 & 0.0246 \\
\hline WS 30 & 0.0127 & 0.0111 & 0.0174 & 0.0069 & 0.0149 & 0.0128 & 0.0081 & 0.0038 & 0.0187 & 0.0107 & 0.0144 & 0.0086 \\
\hline
\end{tabular}


Table 5. The closest coefficients, ranking and priority indices for ranking the existing watersheds in the study area

\begin{tabular}{|c|c|c|c|c|c|}
\hline Watersheds & S+ & S- & Sum & S-/Sum & Priority \\
\hline WS1 & 0.0561 & $\mathbf{0 . 0 3 5 0}$ & 0.0911 & 0.3843 & 16 \\
\hline WS2 & 0.0713 & 0.0426 & 0.1139 & 0.3739 & 19 \\
\hline WS3 & 0.0681 & 0.0282 & 0.0963 & 0.2931 & 27 \\
\hline WS4 & 0.0703 & $\mathbf{0 . 0 3 3 0}$ & 0.1033 & 0.3198 & 23 \\
\hline WS5 & 0.0645 & 0.0415 & 0.1059 & 0.3915 & 14 \\
\hline WS6 & 0.0447 & 0.0462 & 0.0909 & 0.5082 & 6 \\
\hline WS7 & 0.0497 & 0.0448 & 0.0945 & 0.4737 & 7 \\
\hline WS8 & 0.0553 & 0.0425 & 0.0978 & 0.4346 & 11 \\
\hline WS9 & 0.0702 & 0.0232 & 0.0934 & 0.2481 & 30 \\
\hline WS10 & 0.0609 & 0.0364 & 0.0973 & 0.3739 & 18 \\
\hline WS11 & 0.0523 & 0.0426 & 0.0949 & 0.4490 & 10 \\
\hline WS12 & 0.0670 & 0.0305 & 0.0975 & $\mathbf{0 . 3 1 3 0}$ & 24 \\
\hline WS13 & 0.0633 & 0.0400 & 0.1032 & 0.3871 & 15 \\
\hline WS14 & 0.0528 & 0.0444 & 0.0972 & 0.4565 & 9 \\
\hline WS15 & 0.0592 & 0.0362 & 0.0954 & 0.3796 & 17 \\
\hline WS16 & 0.0701 & 0.0318 & 0.1019 & 0.3119 & 25 \\
\hline WS17 & 0.0703 & 0.0240 & 0.0943 & 0.2548 & 28 \\
\hline WS18 & 0.0311 & 0.0720 & 0.1031 & 0.6980 & 1 \\
\hline WS19 & 0.0592 & 0.0417 & 0.1009 & 0.4129 & 12 \\
\hline WS20 & 0.0647 & 0.0378 & 0.1025 & 0.3691 & 20 \\
\hline WS21 & 0.0512 & 0.0459 & 0.0971 & 0.4723 & 8 \\
\hline WS22 & 0.0393 & 0.0546 & 0.0939 & 0.5817 & 2 \\
\hline WS23 & 0.0420 & 0.0494 & 0.0914 & 0.5405 & 5 \\
\hline WS24 & 0.0410 & 0.0518 & 0.0929 & 0.5582 & 4 \\
\hline WS25 & 0.0699 & 0.0371 & 0.1069 & 0.3467 & 21 \\
\hline WS26 & 0.0766 & 0.0261 & 0.1027 & 0.2544 & 29 \\
\hline WS27 & 0.0654 & 0.0290 & 0.0944 & 0.3069 & 26 \\
\hline WS28 & 0.0700 & 0.0346 & 0.1046 & 0.3312 & 22 \\
\hline WS29 & 0.0413 & 0.0537 & 0.0950 & 0.5654 & 3 \\
\hline WS30 & 0.0607 & 0.0423 & 0.1030 & 0.4106 & 13 \\
\hline
\end{tabular}

Table 6. Classification of the watersheds into priority levels based on TOPSIS approach

\begin{tabular}{|cccc|}
\hline \multicolumn{2}{|c|}{ Range of relative closeness to ideal solution } & $\begin{array}{c}\text { Priority } \\
\text { level }\end{array}$ & Watersheds \\
\hline Upper & Lower & $\begin{array}{c}\text { Very } \\
\text { high }\end{array}$ & WS18, WS22, WS29, WS24, WS23, WS6, WS7, WS21 \\
0.698 & 0.472 & High & WS14, WS11, WS8,WS19, WS30, WS5, WS13, WS1 \\
0.472 & 0.384 & Moderate & WS15, WS10, WS2, WS20, WS25, WS28, WS4, WS12 \\
$\mathbf{0 . 3 8 4}$ & 0.313 & Low & WS16, WS27, WS3, WS17, WS26, WS9 \\
$\mathbf{0 . 3 1 3}$ & $\mathbf{0 . 2 4 8}$ & &
\end{tabular}

Comparison of the approaches for (0.80) and the intercept value close is to zero prioritization

Comparison of the results of the two approaches: compound factor computation and TOPSIS approaches revealed that they gave similar results. The high correlation between the priority ranks obtained by these two approaches $(\mathrm{r}=0.80)$ is a good indication of close agreements between them (Figure 2). It can also be noticed from Figure 2 that the slope of the regression line is close to unity
(1.70). Additionally, the non-parametric Wilcoxon signed rank test revealed no significant difference between the observed and the predictive values from the proposed model. The model: $\operatorname{Rank}_{\mathrm{Topsis}}=0.897$ Ran $\mathrm{K}_{\text {compound factor }}+1.704$ can be used to convert the priority obtained from computation of compound factor to assess the rank level from TOPSIS approach with a reasonable accuracy 


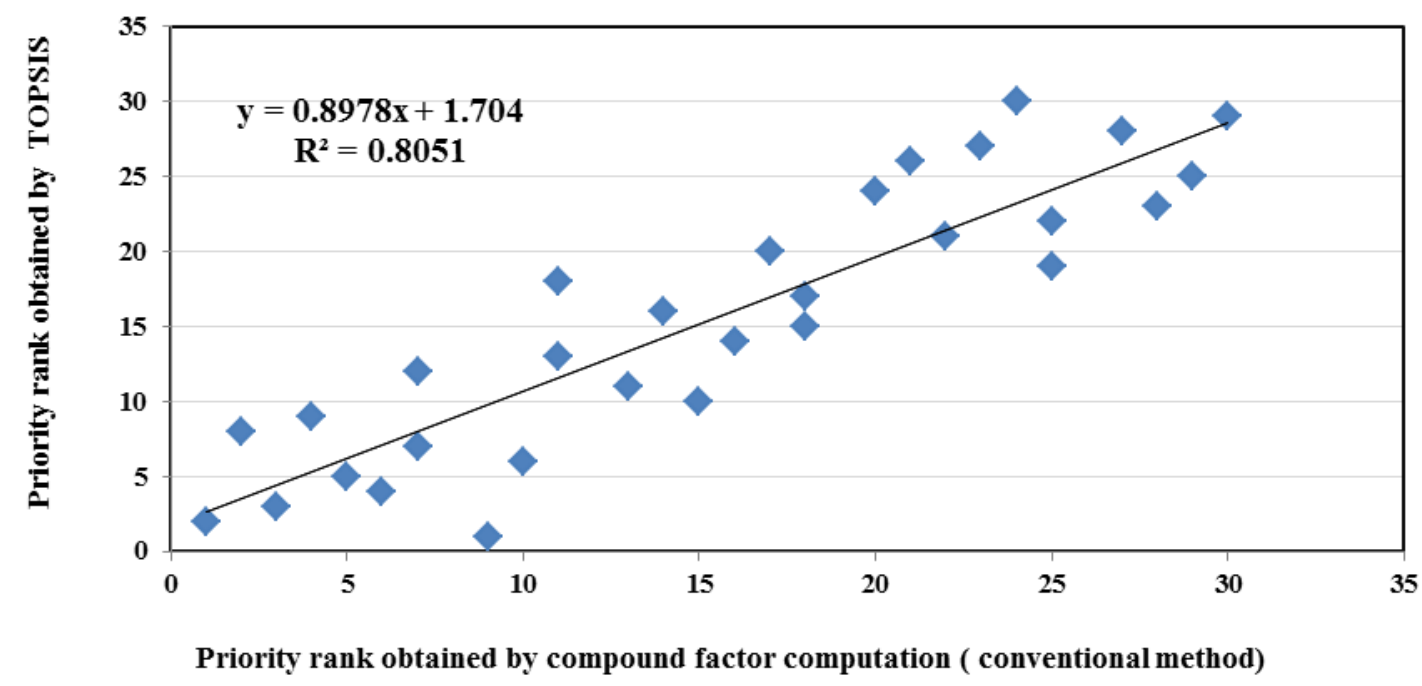

Figure 2. Plot of priority rank obtained by compound factor computation versus priority rank obtained by TOPSIS

\section{REFERENCES1}

1.Abdelfattah, M.A. 2009. Land degradation indicators and management options in the desert environment of Abu Dhabi, United Arab Emirates. Soil Horizons, 50(1): 3-10

2. Al-Khafaji, B. A. A., and A.M. Faris. 2009. An economic analysis of investment in reclamation of agricultural land in Iraq for the period (1989-2006). Iraqi journal of Agricultural sciences, 40 (2): 161-171

3. Arabameri, A., K. Rezaei, H.R. Pourghasemi, S. Lee and M. Yamani. 2018. GIS-based gully erosion susceptibility mapping: a comparison among three datadriven models and AHP knowledge-based technique. Environmental earth sciences, 77 (17): 628.

4. Baumgardner, R. W.1987. Morphometric studies of subhumid and semiarid drainage basin, Texas Panhandle and Northeastern New Mexico. Austin Univ Texas Bur Econ Geol Rept Invest 163:66

5. Biswas S., S. Sudhakar and V.R. Desai 1999. Prioritisation of subwatersheds based on morphometric analysis of drainage basin: a remote sensing and GIS Approach. J Indian Soc Remote Sens 27:155-166

6. Buringh, P. 1960. Soils and soil conditions in Iraq. Ministry of agriculture

7. Chandniha, S.K. and M.L. Kansal. 2017. Prioritization of sub-watersheds based on morphometric analysis using geospatial technique in Piperiya watershed, India. Applied Water Science, 7(1): 329-338
8. Clarke, J.I. 1966. Morphometry from maps. Essays in Geomorphology, 235-274

9. Da Cunha, E.R. and V.M. Bacani. 2016. Morphometric characterization of a watershed THROUGH SRTM data and geoprocessing technique. Journal of Geographic Information System, 8(02): 238.

10. El-Enin, H.A. 1990. The physical geography of the basin of Wadi Dibba in U.A.E. and its effect on agricultural development. Department of Geography, Kuwait

11. Faniran, A. 1968. The index of drainage intensity - a provisional new drainage factor. Australian Journal of Science, 31: 328330.

12. Farhan, Y. and O. Anaba. 2016. A remote sensing and GIS approach for prioritization of Wadi Shueib Mini-Watersheds (Central Jordan) based on morphometric and Soil erosion susceptibility analysis. Journal of Geographic Information System, 8(01): 1

13. Farhan, Y., A. Anbar, D. Zreqat, H. Almohammad and S. Alshawamreh. 2018. Prioritization of promising wadi wala watershed (Southern Jordan) using GIS-based morphometric analysis and multivariate statistics. Open Journal of Geology, 8(02): 135 14. Farhan, Y., A. Anbar, N. Al-Shaikh and R. Mousa. 2016. Prioritization of semi-arid agricultural watershed using morphometric and principal component analysis, remote sensing, and GIS techniques, the Zerqa River 
Watershed, Northern Jordan. Agricultural Sciences, 8(1): 113-148

15. Heshmati, M., A. Abdu, N.M. Majid and J. Shamshuddin. 2013. Land degradation and preventive measures from the perspective of the stakeholders. American Journal of Applied Sciences, 10(9): 061

16. Horton, R.E. 1945. Erosional development of streams and their drainage basins; hydrophysical approach to quantitative morphology. Geological society of America bulletin, 56(3): 275-370

17. Kertész, Á. 2009. The global problem of land degradation and desertification. Hungarian Geographical Bulletin, 58(1): 19-31 18. Magesh, N.S., N. Chandrasekar and J.P. Soundranayagam. 2011. Morphometric evaluation of papanasam and manimuthar watersheds, parts of Western Ghats, Tirunelveli district, Tamil Nadu, India: a GIS approach. Environmental Earth Sciences, 64(2): 373-381

19. Malik, M.I., M.S. Bhat and N.A. Kuchay. 2011. Watershed based drainage morphometric analysis of Lidder catchment in Kashmir valley using geographical information system. Recent Research in Science and Technology, 3(4).

20. Meshram, S.G. and S.K. Sharma. 2017. Prioritization of watershed through morphometric parameters: a PCA-based approach. Applied Water Science, 7(3): 15051519

21. Miller, A. 1953. Skin of the Earth, Methuen \& Co. Ltd., London

22. Nag, S.K. 1998. Morphometric analysis using remote sensing techniques in the Chaka sub-basin, Purulia district, West Bengal. Journal of the Indian society of remote sensing, 26(1-2): 69-76

23. Nitheshnirmal, S., P. Thilagaraj, S.A. Rahaman and R. Jegankumar. 2019. Erosion risk assessment through morphometric indices for prioritisation of Arjuna watershed using ALOS-PALSAR DEM. Modeling Earth Systems and Environment, 1-18

24. Pandey, A., V.M. Chowdary and B.C. Mal. 2007. Identification of critical erosion prone areas in the small agricultural watershed using USLE, GIS and remote sensing. Water resources management, 21(4): 729-746.
25. Patel, D.P, M.B. Dholakia, N. Naresh and P.K. Srivastava. 2012. Water harvesting structure positioning by using geovisualization concept and prioritization of mini-watersheds through morphometric analysis in the Lower Tapi Basin. Journal of the Indian Society of Remote Sensing, 40(2): 299-312

26. Puno, G.R. and R.C.C. Puno. 2019. Watershed conservation prioritization using geomorphometric and land use-land cover parameters. Global J. Environ. Sci. Manage, 5(3), 279-294

27. Rai, P.K., V.N. Mishra and K. Mohan. 2017. A study of morphometric evaluation of the Son basin, India using geospatial approach. Remote Sensing Applications: Society and Environment, 7: 9-20

28 Said, S., R. Siddique and M. Shakeel. 2018. Morphometric analysis and sub-watersheds prioritization of Nagmati River watershed, Kutch District, Gujarat using GIS based approach. Journal of Water and Land Development, 39(1): 131-139.

29. Schumm, S.A. 1956. Evolution of drainage systems and slopes in badlands at Perth Amboy, New Jersey. Geological society of America bulletin, 67(5): 597-646

30. Singh, S. and M.C. Singh.1997. Morphometric analysis of Kanhar river basin. National Geographical Journal of India, 43(1): 31-43

31. Sreedevi, P.D., P.D. Sreekanth, H.H. Khan and S. Ahmed. 2013. Drainage morphometry and its influence on hydrology in an semi-arid region: using SRTM data and GIS. Environmental Earth Sciences, 70(2): 839-848.

32. Srivastava, P.K., S. Mukherjee and M. Gupta. 2010. Impact of urbanization on land use/land cover change using remote sensing and GIS: a case study. International Journal of Ecological Economics and Statistics, 18(S10): 106-117

33. Strahler, A.N. 1964. Quantitative geomorphology of drainage basins and channel networks. In V. T. Chow (Ed.) New York: McGraw Hill., Handbook of Applied Hydrology. 4: 39-4 and 76

34. Sujatha, E.R., P. Kumaravel and G.V. Rajamanickam. 2014. Assessing landslide susceptibility using bayesian probability-based 
weight of evidence model. Bulletin of Engineering Geology and the Environment, 73(1): 147-161

35. Suliman, A. A. and L. F. Gar. 2012. Use of some morphometric parameters to study the patterns, forms and distribution of some major soil series of Latifiya and Diyala a projects. Iraqi Journal of Agricultural Sciences, 43 (special issue-4), 15-21

36. Suresh, R. 2007. Soil and water conservation engineering. Standard Publishers and Distributors, Delhi, 799-812

37. Tavassol, S.F. G.S. and Gopalakrishna. 2016. GIS-based morphometric analysis of major watersheds of Tehran-Karaj, Central of Iran. Int. J. of Life Sciences, 4: 1

38. UNESCO, 1979. Aridity definition (UN documents) United Nation Educational Scientific and Cultural Organization, New York

39. Vittala, S.S., S. Govindaiah and H.H. Gowda. 2008. Prioritization of sub-watersheds for sustainable development and management of natural resources: an integrated approach using remote sensing, GIS and socio-economic data. Current Science, 345-354

40. Walsh, R.P.D. and D.M. Lawler. 1981. Rainfall seasonality: description, spatial patterns and change through time. Weather, 36(7), 201-208

41. Wandre, S.S. and H.D. Rank. 2013. Assessment of morphometric characteristics of Shetrunji river basin using remote sensing and GIS. International Journal of Agriculture, Environment and Biotechnology, 6(3): 503514

42. Wheib, K.A. 2012. Spectral reflectance properties of soil surface and land covers of AL-Salman depression in southern Iraq. Iraqi Journal of Agricultural Science, 43 (special issue-4): $129-140$

43. Zia-ur-Rehman, M., G. Murtaza, M.F. Qayyum, M. Rizwan, S. Ali, F. Akmal and H. Khalid. 2016. Degraded soils: origin, types and management. In Soil Science: Agricultural and Environmental Prospectives, 23-65, Springer, Cham. 